Original Article

Received/Accepted

Dates

19.04.2021/21.05.2021

DOI

10.52096/jsrbs.6.1.7.13.11
Journal of Social Research and Behavioral Sciences

Sosyal Araştırmalar ve Davranış Bilimleri Dergisi

ISSN:2149-178X

Volume: 7 Issue: 13 Year: 2021

\title{
İspanya Dış Politikasında İmparatorluk Geçmişi ve Latin Amerika ${ }^{1}$
}

\author{
Doç. Dr. Filiz ÇOBAN ORAN \\ Çanakkale Onsekiz Mart Üniversitesi \\ Uluslararası İlişkiler Bölümü \\ filizcoban@comu.edu.tr \\ Adem Emre KÖSE \\ Çanakkale Onsekiz Mart Üniversitesi \\ Uluslararası İlişkiler Bölümü
}

\section{Özet}

İspanya dış politikasında İspanyolca konuşan Latin Amerika ülkeleriyle ilişkiler tarihi ülkenin imparatorluk geçmişine uzanan özel ve ayrıcalıklı bir yere sahiptir. Latin Amerikalı halklarla paylaşılan kültürel tarih, kimlik ve ortak dil anlatısına dayanarak, İspanya hala diplomatik ilişkilerde, kültürel yatırım ve dış yardımda öncü rolünü bütün ülkelerden daha fazla sürdürmeyi amaçlamaktadır. Ayrıca, bu bölgeyle devam eden ilişkiler Madrid'in İber yarımadasından tüm dünyaya uzanan küresel rolü için dış politikasının en temel alanlarından biridir. İspanya, Latin Amerika ile ilişkilerinde İber-Amerikan kimliğine vurgu yaptığ 1 için, bu çalışma çağdaş İspanya dış politikasında Latin Amerika'nın yerini sosyal-inşacı yaklaşımla analiz etmeye çalışmaktadır. Özellikle, İspanya'nın Avrupa Birliğine üyeliğinin bu ilişkilere etkisini araştırmaktadır. Sonuç olarak, ulusun Avrupa kimliğinin 1980’lerdeki demokratikleşme sürecinden beri İber-Amerikan kimliğinden daha fazla ağırlık kazandığını iddia etmektedir. Bu nedenle, Avrupa ile ilişkiler, Latin Amerika'yı dış ilişkilerde ikincil pozisyona itmiştir.

Anahtar kelimeler: İspanya dış politikası, ulusal kimlik, Latin Amerika, Avrupa kimliği

Jel Kodları: F68, N44, N46

\footnotetext{
${ }^{1} \mathrm{Bu}$ çalışma ÇOMÜ Bilimsel Araştırma Projeleri Koordinasyon Birimince Desteklenmiştir. Proje Numarası: SYL2020-3285
} 


\section{The Imperial Past and Latin America in Spain's Foreign Policy}

In Spain's foreign policy, the relationships with the Spanish-speaking Latin American countries have a special privileged place which dates back to the country's imperial past. Based on a narrative of common language and a shared cultural history and identity with the Latin American people, Spain still aims to maintain its leading role in diplomatic relations, cultural investment, and foreign aid more than any country. Moreover, the ongoing relationships with this region has been one of the key areas of Madrid's foreign policy for its global role expanding from the Iberian Peninsula to the entire world. Since Spain emphasises on the concept of Ibero-American identity in its relations with the Latin America, this study attempts to use a social-constructivist approach in analysing the place of the Latin America in the contemporary Spanish foreign policy. Specifically, it searches for the influences of Spain's European Union membership on these relationships. Consequently, it argues that European identity of the nation has gained a greater weight than its Ibero-American identity since the democratisation process of 1980s. Thus, the relationships with Europe have pushed the Latin America to a secondary position in the foreign affairs.

Key words: Spanish foreign policy, national identity, Latin America, European identity

\section{Giriş}

Bugünkü ulus-devletleri, uluslararası sistemin yapısını, kurumlarını ve işleyişini daha iyi anlamak için imparatorluklar döneminin aktörler ve ilişkiler üzerindeki etkisine, süreklilik ve değişime bakmak gerekir (Halperin and Palan 2015). Bu bağlamda İmparatorluk geçmişi olan bir Akdeniz ve Avrupa ülkesi olan, gerek ideolojik gerek kimlik temelinde siyasal kutuplaşmalar yaşayan İspanya'nın iç ve dış politikadaki deneyimleri önemli bir örnek teşkil etmektedir. İspanya dış politikasını ele alan çalışmalar İngilizce literatürde sınırlı sayıda olduğu gibi, Türkçe Uluslararası İlişkiler çalışmalarında yok denebilecek kadar azdır. Geçmişte bir imparatorluğa sahip olan İspanyolların günümüzde kendi dillerini ve kültürlerinin izlerini taşıan Latin Amerika ile ilişkilerinin nasıl olduğu ve Avrupa Birliği çatısı altında kendi kimliklerini nereye koydukları dikkat çekici bir sorudur. Dolayısıyla İspanya dış politikasında Latin Amerika kimliğinin ve Avrupa kimliğinin ne derece önemli olduğu sorusu bu çalışmanın temel araştırma problematiğini oluşturmaktadır. Bunun için bu çalışma, dış politika analizi yaklaşımları içinde kimlik ve kültürü temel alan Sosyal-inşacılık yaklaşımını kullanmaktadır. 
Uluslararası ilişkilerde baskın geleneksel Realist yaklaşım (Morgenthau 1970, Waltz 2000) dış politikada askeri güç, ekonomik kapasite gibi materyal olguların üzerine kurulu bir analiz çerçevesi sunarken, Sosyal-inşacıllk yaklaşımı ise en önemli olgunun materyal değil, sosyal olduğunu ileri sürmektedir (Jackson \& Sorensen, 2007: 162). İnşacılık yaklaşımının en önemli çıkış noktalarından biri sosyal dünyanın hazır veriler ile sunulmuş bir dünya değil, inşa edilmiş oluşturulmuş bir dünya olduğu savıdır (Maja, 2002: 4). Niclolas Onuf (2012: 1), Alexdander Wendt (1992: 395), Friedrich Kratochwill (1995: 43), Peter Katzenstein (1996) ve Martha Finnemore (1996) gibi yazarlar bu yaklaşımın önde gelen eserlerini yayımlamışlardır. Bu yaklaşıma göre devletler dış politika yapım sürecinde diğer devletlerle ilişkisinde kimliklerini ilişkisel olarak belirlemekte ve buna göre güvenlik ya da tehdit kavramlarını kurup dış politika tercihlerini saptamaktadır. Dolayısıyla bu çalışma teorik olarak kimliklerin dış politika yapım sürecinde etkili olduklarını öne sürerek, İspanya dış politikasında imparatorluk kimliğinin ve Latin Amerika ile ilişkilerin yerini araşııımayı amaçlamaktadır.

$\mathrm{Bu}$ çerçevede araştırmanın temel dört aşaması vardır. İlk aşamada İspanya'nın imparatorluk geçmişine ve sömürgecilik dönemine ışık tutulacaktır. İkinci aşamada İspanya'nın imparatorluktan ulus-devlet yönetimine, bir başka deyişle, sömürgecilik döneminden iç savaşa ve Franco rejimine geçişi Latin Amerika ve Avrupa güçleriyle ilişkiler bağlamında ele alınacaktır. Üçüncü aşamada İspanya'nın demokratikleşmesine, Soğuk Savaş döneminde Batı bloğuna katılışının yanı sıra Latin Amerikalı ülkelerle işbirliği çerçevesinde dış politikada İber-Amerikan kimliği inşasına açıklık getirilecektir. Son olarak dördüncü bölümde İspanya'nın Latin Amerika ile ilişkilerinin açmazlarına odaklanarak, iç ve dış politikada Avrupalılaşmanın öneminin altı çizilerek çalışmanın temel sorusuna cevaplar aranacaktır.

\section{1-İspanya'nın İmparatorluk Geçmişi ve Kimliği}

Günümüzde İspanya Devleti ve Portekiz Devletini barındıran İber Yarımadası, çok geniş ve zengin bir tarihe sahiptir. İber yarımadası geçmişten beri birçok yol ayrımına ev sahipliği yapmış ve ayrıca Avrupa ve Afrika, Avrupa ve Atlantik okyanusu ve bağlantılı olarak Atlantik ülkeleri ile Avrupa devletlerinin iletişim noktası haline gelmiştir. Milattan Önce (M.Ö.) 200 yıllarda Roma İmparatorluğu İber yarımadası ile ilgilenmeye başlamıştır. O dönemde Tunus dolaylarında gelişme gösteren Kartaca kent devleti Roma İmparatorluğu tarafından tanınmıştır. Kartaca devletinin 
ilerlemeci politikası İber yarımadasına da sıçramış ve bu durum Roma İmparatorluğu'nun dikkatini çekmiş̧ir (Phillips and Phillips 2016: 32-33). Kartaca devleti ile girilen savaşlarda Roma üstünlüğünü sağlamış ve milattan sonra dördüncü yüzyıla kadar egemenliğini sürdürmüştür (Kurul, 2015: 4). Bu dönemde Roma devleti İspanya bölgesinin kalkınmasına büyük katkılar sunmuştur. Dil, din ve hukuk alanında büyük gelişmeler olmuştur. Ayrıca başta Kartaca devletinin etkisini kaldırmak için adayı ele geçirmiş gibi olsa da zamanla adanın maden ve arazi gelirlerinden faydalanmaya başlamıştır (Phillips and Phillips, 2016: 36-37).

Roma İmparatorluğu'nun IV. yüzyılda zayıflamasıyla birlikte İber bölgesine Vizigotlar girmeye başlamıştır. Vizigotlar Roma İmparatorluğu'na büyük saygı duyan bir topluluk olmuş ve bölgenin Roma himayesinde yönetilmesi için katkıda bulunmuştur. Ancak Roma devletinin verdiği sözleri tutmaması sonrası Vizigotlar İspanya'yı işgal etmeye başlamış ve nihayetinde Roma ile savaşa girmiş̧ir. Savaş sonucunda ağır yenilgi alan Roma devleti şehirden çekilmiş ve Vizigotları kendi içlerinde bağımsız dış politikada Roma'ya bağlı olmaya ikna etmiştir (Çapan \& Güvenç, 2017: 7). M.S 710'da Müslümanların yarımadaya gelmesi ile Vizigot yönetimi sona ermiştir. Tarık bin Ziyad önderliğinde fetih hareketlerini gerçekleştiren Müslümanlar M.S 716'ya gelindiğinde Müslümanlar adanın büyük bir kısmını ele geçirmiştir (Makki, 1992: 8). M.S 732 yılına gelindiğinde Avrupa'ya yönelik fetih hareketlerini artıran Müslümanlar Fransa'ya ilerlemiş ve Bordeaux’yu almışlardır. İlerlemeye devam eden Müslümanlar Frank lideri Charles ve ordusu ile savaşa girmiş ancak önemli bir yenilgi almamasına rağmen ilerleyişini durdurmuştur (Üçok, 1968: 59-60). Coğrafya 1031 yılına kadar kesintisiz şekilde Müslümanların hâkimiyetinde kalmıştır. 1031 yılında halifeliğin son bulması ile Müslümanlar kendi içinde devletçiklere bürünmüştür. Kendi aralarında yarışa girmeleri Hristiyanlar tarafindan da desteklenmiş ve bu süreçte Müslümanlar zayıflarken Hristiyanlar güçlenmiş̧tir (Özdemir, 1992: 244). 1249 yılına gelindiğinde ise Müslümanların elinde sadece Gırnata emirliği kalmıştır. Gırnata emirliğinde kurulan son Müslüman devlet Ben-i Ahmer devleti olmuştur. 1350 yılında çıkan veba salgını ile Hristiyanların Müslümanların üzerine çok fazla gidememesi sonucunda 1492'ye kadar Ben-i Ahmer devleti varlığını sürdürmüştür. 1469 yılında Aragon kralı Fernando ve Kastilya kraliçesi Isabel'in evlenmeleri ile Hristiyan birliği güçlenmiş ve Müslümanların üzerine daha etkili şekilde gelmeye başlamıştır (Lee, 2004: 57). 1482 - 1492 yılları arasında süren saldırılar nihayetinde 1491'e gelindiğinde artık Hristiyanlar birçok toprak elde etmiş̧tir. Nihayetinde Gırnata emiri XII. Muhammed Kasım 1491'de Fernando ve Isabel ile bir anlaşma imzalamıştır (Hitti, 2011: 585). 
Isabel ve Fernando'nun Kastilya ve Aragon krallıklarını birleştirmesi ve bir bütün İspanya temelini atmaları toplumu da bir bütün olarak algılayacaklarını göstermiştir. İç politikada daha önce kullanılmış uygulamalar terk edilmemiş ve yeni politikalar eklenerek tasarlanmıştır. Kraliçe Isabel bu dönemde limanlara çok önem vermiştir. Birçok liman yapımı için kraliyet bütçesinden kaynak sağlayan Isabel, 1492'de Müslümanların elinden tamamen aldığı Gırnata’nın liman avantajını da kullanarak deniz ticaretini desteklemiş ve deniz hâkimiyeti sayesinde krallığını daha güvence altına almak istemiştir. İlk etapta İspanya coğrafyasına yakın Madeira ve Kanarya adalarını işgal etmek için kraliyet bütçesinden destek sağlanmıştır. Adadaki yerli halkların bazıları ile anlaşılmış olsa da birçoğu saf dışı bırakılmıştır. Artık XV. yüzyılın sonlarına gelindiğinde işgal edilen adalarda tarım yapılmaya başlanmıştır. Portekiz XIV. yüzyılın sonlarında kâşif Bartelmo Diaz’1 keşif yapması için görevlendirmiştir. Diaz 1486'da ilk defa Ümit Burnu'na ulaşan kişi olmuştur. Bu durumu fark eden kraliçe Isabel, Portekiz’in denizlerdeki üstünlüğünün önüne geçmek için bir şeyler yapılmasına karar vermiştir. Portekiz ile bir savaşa girmeden yeni keşif yolları bulmak isteyen Isabel ve Fernando, Kristof Kolomb'un merak uyandıran planını kabul etmiştir. Ancak Gırnata'lı Müslümanlar ile savaşta oldukları için planı biraz ertelemek istemişlerdir. Kolomb’u ellerinden kaçırmamak için Kastilya'daki tüm masraflarını karşılamışlardır. Nihayetinde 1492'de savaş bittiğinde Kolomb’a gereken desteği vereceklerini belirtmişlerdir. Yolculuğa çıkmadan önce Kolomb ile bir anlaşma yapan Isabel ve Fernando, keşif sırasında elde edeceği kârın tahtla paylaşması konusunda Kolomb’u ikna etmiştir. Kolomb ise karşılığında başarılı olursa asil statüsü istemiş ve fethettiği bölgelerin valisi olmayı talep etmiş ve talebi kabul görmüştür (Padron, 1990: 106). 1492'de Kolomp denize açılmıştır. Bir aylık bir süre sonrası Bahamalar'da bir adaya ulaşmış ve Japonya'ya yaklaştığını düşünmüştür. Donanması karaya çıktıktan sonra ilerlemeye devam etmiş ancak Kolomb farklı bir gemi ile keşfe devam etmiştir. Küba'nın doğu ucuna ilerleyen Kolomb, burada günümüzde Hispanyola adındaki adayı keşfetmiştir (Berrak, 2005: 876).

$\mathrm{Bu}$ dönemde hareketlenen coğrafi keşifler Avrupa kimliğini ve Avrupa karakterini ortaya çıkarmıştır. Coğrafi keşiflerin Avrupalı devletlerce yapılması ve zenginliklerin Avrupa'da toplanması bu kıtayı güçlendirmiştir. Birçok değişimi kısa sürede gerçekleştirmeye başlayan Avrupalı devletler diğer alanlarda da gelişimlerine devam etmişstir. Bilimde ve sanatta yaşanan tüm kültürel gelişmeler, Avrupa'da yavaş yavaş özgün bir ortamın oluşmasını sağlamış ve Avrupa kimliğinin temelleri bu süreçte atılmıştır. 1516 yılına gelindiğinde Fernando ve Isabel'in ölmesi ve kızları Juana'nın yönetemeyecek derece sağlık sorunları olması sebebiyle torunları Carlos 
Kastilya, Aragon ve İspanya dışındaki toprakların tek varisi konumuna gelmiştir. 1517 yılında kral Carlos İspanya'ya geldiğinde üç ana soruna çözüm bulmak zorunda kalmıştır. Bu sorunlar sırası ile İslam âlemi ile mücadele, Kastilya'nın sömürgeler keşfederek imparatorluk olmasındaki mücadele ve birleşik bir Hristiyan Avrupa yaratma fikri olmuştur. Carlos 1556'ya kadar yönetimi boyunca Fransa ile mücadeleye girişmiştir. Kuzeni Lojos'un 1526'da Mohaç muharebesinde Osmanlı kuvvetlerince öldürülmesi sonucu Osmanlı'yı ve Müslümanları kişisel meselesi haline getirmiştir. Sömürgecilik faaliyetlerine aktif olarak devam eden İspanya, günümüzde Bolivya olarak bilinen Potosi'deki maden yataklarını yağmalamıştır. Buradan çıkarılan çeşitli madenler ile hem İspanya imparatorluğu güçlenmiş hem de Avrupa ekonomisi canlanmıştır. 1556'da Carlos tahtını oğluna bıraktığında II. Felipe küresel bir imparatorluğun zirvesinde bulunan bir imparator konumuna gelmiştir (Chapman, 2010). II. Felipe de babası gibi Osmanlı ile mücadele içine girmiştir. 16. yüzyılın başlarında Orta Avrupa'ya kadar ilerleyip Viyana'yı kuşatan, Ege'de, Akdeniz'de ve Kuzey Afrika'da etkin olan Osmanlı İmparatorluğu, stratejik bakımından aşırı genişleme belirtileri göstermiştir (Kennedy 2005: 36). Kanuni Sultan Süleyman'dan sonra tahta geçen on üç sultan gerilemeyi engellememiştir. Bunu firsat bilen İspanya, Papalık ve Venedik ile 'Sürekli Kutsal Lig' oluşturarak (Sander 2004: 110) 1571 yılında İnebahtı deniz savaşında Osmanlıyı yenilgiye uğratmayı başarmıştır. Bundan altı ay sonra Kaptanı Derya Uluç Ali, Kıbrıs'ı ve Tunus'u geri alarak imparatorluğun etkisini Fas'a kadar sürdürmüsşür. Öte yandan 1578'de Portekiz Kralı Sebastian'ın Fas'a düzenliği seferde hayatını kaybetmesi sayesinde İspanya Kralı’nın Portekiz tacını elde etmesi kolay olmuştur (Pierson, 2010: 66).

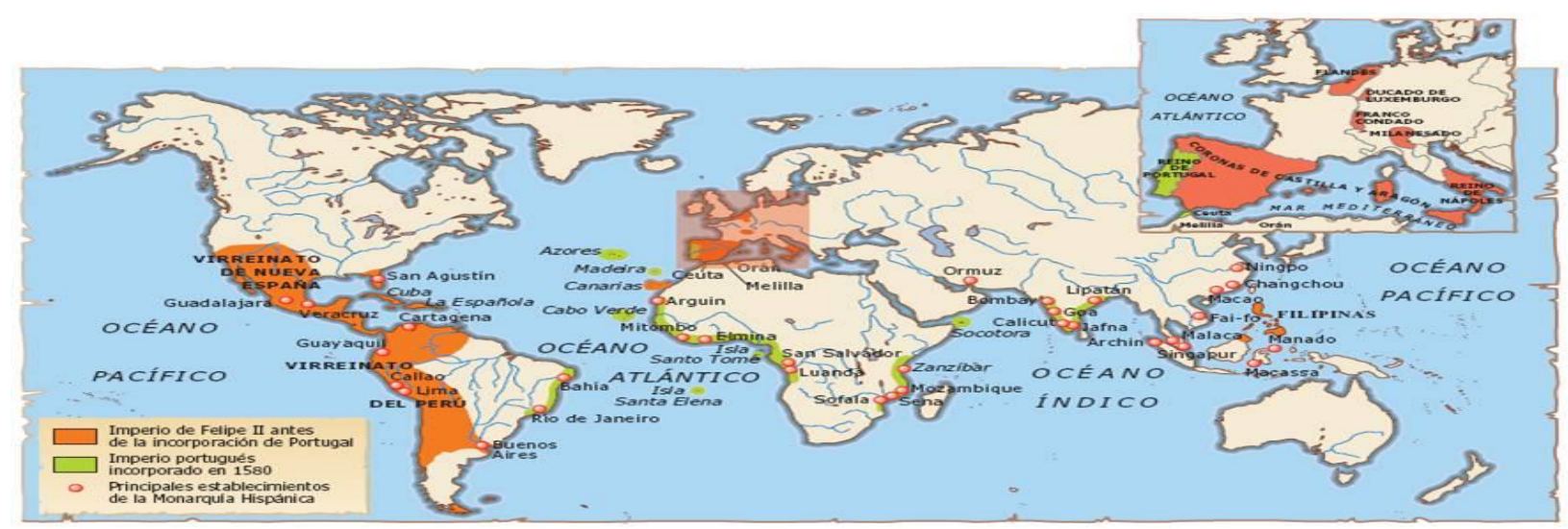

Kaynak: https://mundoantiguo.net/imperio-espanol/ 
1598 'de tahta geçen III. Felipe ve 1621 'de tahta geçen IV. Felipe dönemlerinde İngiltere ile mücadeleye devam edilmiştir. Özelikle IV. Felipe döneminde kültürel çalışmalara önem verilmiş ve İspanya'nın dünyaca ünlü Prado müzesinin temelleri atılmıştır. 1621'de tahta çıktığ sırada kuzey Hollanda eyaletleri yapılan anlaşma sona ermişsir ancak Almanya'da Otuz Yıl savaşları başlamışıtır. En nihayetinde bir Katolik - Protestan savaşı olarak görünmüş olsa da birçok devletin bir araya gelmiş olması ile siyasi bir görünüm almıştır. Savaşı Protestanlar kazanmış ve 1648'de Westfalya anlaşması imzalanmıştır. IV. Felipe döneminde dış ilişkiler başarıdan başarısızlığa dönüşmüştür. Önceki dönemde başlayan ekonomik gerilemeye çözümler üretilmemiş ve artarak devam etmiştir. IV. Felipe sonrası iyice zor duruma düşen krallığın başına II. Carlos geçmiştir. Fransa'nın yoğun saldırıları sonrası kraliyet İspanya'yı yönetmekte zorlanmıştır. Yaptığı evlilikle çocuk sahibi olamayan Carlos 1700 yılına geldiğinde bir varis belirlemek zorunda kalmış ve şaşırtıcı şekilde Fransız Bourbon hanedanından XIV. Louis'in torunu Philippe'i varisi ilan etmiştir. V. Felipe adı ile 1700 'de tahta çıkmıştır. 746 yılına kadar bir güven ve istikrar sağlayamayan İspanya taht1 VI. Fernando'nun tahta çıkmasıyla başka bir politik istikrara kavuşmuştur. Otuzlu yaşlarında, tecrübeli ve eğitimli olarak tahta çıkan Fernando babasının sürdürdüğü Fransa ittifakını sonlandırmış ve barışçı bir politika izlemiştir (Pierson, 2010: 77). Devlet kademesindeki önemli noktalara iyi eğitimli kişileri yerleştirmiş ve politikalarının güvenilir şekilde uygulanmasını sağlamıştır. İki önemli danışmanı Carvajal ve Ensenada ile devletin gücünü artıran Fernando birçok alanda çalışmalar yapmıştır. Ensenada Fransız yanlısı bir politikayı desteklerken, Carvajal daha barış̧̧ı ve bağımsız bir politikayı desteklemiştir. Carvajal'a göre İspanya'nın deniz aşırı topraklarının korunmasının tek yolu İngiltere ile bir anlaşma yaparak toprakların korunması olmuştur. Ensenada ise toprakların güvenliği ve imparatorluğun devamı için Fransa ile ittifak yapılmasını tavsiye etmiştir. Nihai noktada iki taraf ile de bir ittifak olmamış ve tarafsız bir politika tutumu gerçekleştirilmiştir. Ensenada ise 1754 yılında görevinden ayrılırken birçok kazanım bırakmıştır. 1753 yılında Vatikan ile görüşmelere başlayan Ensenada, papalık ile İspanyol tahtı arasındaki bağlantıyı kurmuş ve kralın koltuğunu sağlamlaştırmıştır. Ayrıca İspanya'nın ekonomisinin ve donanmasının daha güçlü hale gelebilmesi için İspanyol denizciliğinin geliştirilmesini savunmuştur. Görevi bıraktığında İspanya donanması eski gücüne yakın duruma gelmiştir. Fernando sonrası tahta çıkan IV. Carlos döneminde ise iç politika ve reformlar önem kazanmıştır. IV. Carlos'un en meşhur bakanı olan Manuel Godoy bu reformlarla ilgilenmiştir. 
Ancak iç reformlar düşünülürken dış siyasette gerçekleşen Fransız ihtilali temkinli bir şekilde takip edilmiştir.

1796 yılında İspanya donanması hazırlıksız iken Fransa'nın İngiltere'ye savaş ilan etmesi ile İspanya'da savaşa girmiş ve kaybetmiştir. 1799'da Napolyon Bonaparte Fransa devletinin başına geçmiştir. 1807 yılında Fransa - İspanya arasında yapılan Fontainebleau anlaşmasına göre İspanya büyüyen Fransa ve Napolyon hanedanlığını kabul etmiş ve zayıflığını göstermiştir (Phillips and Phillips, 2016: 212). 1808 yılında hedef olarak Portekiz işgal etmek amacı ile yola çıan binlerce Fransız asker İspanya' yı işgal etmiş̧tir. Kral IV. Carlos ise tahtı Napolyon'a teslim etmiştir. Bunun üzerine 6 Mayıs 1808 tarihinde Napolyon abisi Joseph'e İspanya tahtını sunmuştur. Yapılan saldırılar ve baskılar sonucu Joseph tahtta fazla kalamamış ve 1813'te Fransa'ya kaçmıştır. 1828 yılında ise Fransızlar tamamen İspanya'dan çekilmiştir. Bu süreçte Güney Amerika'daki sömürgelerde ayaklanmalar başlamış ve yirminin üstünde sömürge bağımsızlığını ilan etmiştir. 19. yüzyılda İspanya dış politikada kayıplar vermiş ve iç siyasetinde çalkantılar yaşamıştır. 1895 'te Küba'da isyanlar çıkmış, İspanya'ya karşı Amerika Birleşik Devletleri (ABD) Küba'nın koruyuculuğunu üstlenmiştir. Birkaç yıl içinde gerek Küba sorunu gerek ABD'de yükselen Katolik düşmanlığı iki devleti savaşa sürüklemiştir. Küba ve Filipin kıyılarında iki tarafın karşı karşıya gelmesi sonucunda İspanya ağır bir yenilgi almıştır (Pierson, 2010: 112). Yenilgi sonrası iç siyasette reform sesleri yükselmeye başlamıştır. İç siyasetteki çatışmalar ve bir türlü istikrarın sağlanamaması 1923 yılına kadar devam etmiştir. 1923 yazında Katalonya'da askeri vali olarak bulunan General Miguel Primo de Rivera, 13 Eylül'de Barselona'da bir muhtıra yayınlamıştır. İş adamlarının da desteğini arkasına alan Primo hükümet değişikliği talebinde bulunmuştur. Kral XIII. Alfonso ile görüşen General Primo hükümeti kurmak için onay almıştır. Ancak mevcut 1876 Anayasası ve Cortes yapısı içinde bir hükümet kurmak yerine sorunların çözülebilmesi için bir askeri hükümetin kurulmasının gerekli olduğunu vurgulamıştır. Kısa süreli bir askeri diktatörlük olarak tanımlanan dönem XIII. Alfonso tarafından da kabul edilmiştir. Eylül 1923 yılından Aralık 1925'e kadar olan süreci içerecek iki yıllık bir askeri diktatörlük dönemi Kral Alfonso'nun rızası ile başlamıştır. General Primo göreve başlar başlamaz liberal ve muhafazakâr partileri kapatmış ve onların yerine 1924 yılında Union Patriótica (Yurtsever Birlik) partisini kurmuştur. 1925 yılında Fas'taki Abdulkerim birliklerine karşı Fransa ile bir anlaşma imzalayan İspanya zafere ulaşmıştır. $\mathrm{Bu}$ durumun yaşanması üzerine General Primo anayasaya dayalı monarşiye kısa bir ara vaadinden vazgeçerek kalıcı diktatörlük için çaba sarf etmiştir. Ancak yaşanan süreçte gittikçe destekçileri 
azalan General Primo, nihayetinde 1930'da istifa etmiştir. Yaşanan bu çalkantılı süreç 1936'da iç savaşa kadar tırmanmıştır (Pierson, 2010: 125-132).

\section{Franco Faşizm ve Hispanidad}

İç savaşta olayların kontrol edilemez bir hale geldiğinde Francisco Franco önderliğinde Fas'ta ayaklanma başlamıştır. Ordunun büyük bir kısmına hâkim olan isyancılar kısa sürede ülkenin üçte birine yerleşmiştir. Avrupalı devletler kendi aralarında imzaladıkları pakt gereğince her iki tarafa yardım etmeme kararı almıştır. Ancak Almanya ve İtalya'da ortaya çıkan faşist yönetimler milliyetçiler safındaki Franco'ya hem asker hem de teçhizat yardımı yapmaya devam etmiştir. Cumhuriyetçilere Sovyetler Birliği silah yardımında bulunmuştur. Nihayetinde Hitler'in Çekoslovakya’yı işgal etmesi üzerine Sovyetler Birliği gücünü oraya çekmiş ve cumhuriyetçilere verdiği desteği sonlandırmıştır. Franco birliklerinin 1939'da önce Katalonya'yı sonrasında ise Madrid'i ele geçirmesi savaş sonlanmıştır. Öncelikle İngiltere ve Fransa, sonrasında ise 1 Nisan 1939’da ABD Franco hükümetini tanıdığını ilan etmiştir. Franco mecliste herkesi temsil edecek bir partinin kurulacağını bildirmiş ve savaşta ölen General Primo'nun oğlu Jose Antonio Primo'nun anısına Falanj partisini devam ettirmiştir. Partinin kadın kollarına ise Antonio'nun kız kardeşi Pillar Primo’yu atayarak Falanj partisinin gücünü arkasına almak istemiştir. Bu sırada İkinci Dünya Savaşı patlak vermiş ve Almanya'nın destek istemesi sonrası Franco, Mavi Tümen adını verdiği askerlerini Almanya’ya göndermiştir (Dönmez, 2018). 1942 yılının sonlarında Mihver devletlerin savaşı kaybedeceğini anlayan Franco desteğini sonlandırmıştır. Savaş sonunda hazırlanan devletler listesi sonunda 1945 'te Birleşmiş Milletler kurulmuş ve İspanya savaşta devrilmeyen tek diktatörlük olarak üyelikten çıkarılmıştır. Franco, 1947'de rejiminin kralsız krallık olduğunu açıklamış ve ölümü sonrasında krallığın geri geleceğini belirtmiştir.

Dolayısıyla Franco döneminde geçmişin etkisi ulus-devlet kimliğini yeniden tanımlama ve ulusun dünya ulusları arasındaki yerini belirlemede son derece etkili olmuştur. Bu tarihi, dini ve arketip değerleri ve ilkeleriyle Francocu kendini tanımlama ve propaganda bir tür 'Barok İspanya' tahayyülüdür (Grobmann, 2014: 762). Öte yandan bu dönemde çokça vurgulanan 'hispanidad' (İspanyol dünyası) kavramı Franco'nun herhangi bir dönemle sınırlı olmaksızın tarihi ve dini tahayyülü rejimin siyasi otoritesini güçlendirmek için kullanmasına hizmet etmiştir. Ayrıca bu kavramla İspanyolca konuşan Latin Amerika ülkeleriyle ilişkiler geliştirerek uluslararası izolasyon 
aş1lmaya çalışmıştır (Wang, 2016: 6). Anglo-Sakson dünyadan kültürel olarak farklı olan Hispanik toplumların kardeşliği ve ortak kaderine vurgu yapan bu kavram İspanya'yı Latin Amerika haklarının bir parçası olarak gören yaklaşımın anahtar kavramlarındandır.

1950'li yılların henüz başında ABD ve SSCB arasında Soğuk Savaş dönemi alevlenmiştir. Komünizm karşıtı Franco, Batı bloğuna girmek ve ABD 'nin bir müttefiki olmaya çalışmıştır. Bunun için Bakan Martín Artajo, NATO'ya girebilmek için Nisan 1953'te altı Arap ülkesine ziyarette bulunmuş, Arap ülkelerini, Portekiz, Türkiye ve Yunanistan'ı da içine alan komünizme karşı bir Akdeniz Paktı oluşturmayı önermiştir. Bu çaba Fransa ve İngiltere'nin kesin bir muhalefetiyle karşılandığı gibi bölge ülkelerince de güvenilir bulunmamıştır (Sanz 2001: 53). Aynı zamanda İspanya Vatikan ile yeni bir anlaşma imzalamış ve bu sayede Franco İspanya'daki Roma Katolik Kilisesi üzerinde otorite sahibi olmuştur. Başkan Dwight D. Eisenhower'ın diş politika doktriniyle ABD'nin bölgeye ilgisi artınca ekonomik kapasitesi son derece kısıtlı olan İspanya'ya askeri ve ekonomik yardım sağlamak amacıyla Madrid Paktı'nı imzalamıştır. Bu pakt kapsamında askeri ve mali yardım desteği sözü alan İspanya karşıllı̆ında üç hava üssü sözü vermiş̧tir. Batı demokrasilerince hoş karşılanmasa da İspanya Batı kampına dâhil olmuştur. 1962'de yayınlanan Dünya Bankası raporuna göre İspanya'nın yabancı yatırımları ülkeye çekebilmesi için büyük firsatlar sunması gerektiği vurgulanmıştır. Bu durum üzerine Franco deneyimli iktisatçılardan oluşan bir grubu göreve getirmiştir. Bu yeni ekonomide reform grubunun göze çarpan ismi Laureano López Rodó olmuştur. Rodo bir dizi ekonomik reformu uyguladıktan sonra istihdama pozitif etkisi sebebiyle tarım yerine sanayiye önem vermiştir. Sanayi reformunun uygulanmaya başlaması ile kırsal kesimdeki nüfus büyük şehirlere göç etmeye başlamış ve bölgesel işsizlik azalma eğilimine girmiştir. İspanya ekonomisi dünyaya açılmasıyla birlikte 19601973 yılları arasında Avrupalı komşularından daha fazla büyümüştür. 1969 yılında muhalefet güçleri taleplerini artırmıştır. Batı devletlerinde çıkan protestolar İspanya'ya da yansımış ve kuzey bölgesi olan Bask'da ETA bu dönemde silahlı eylemlerine başlamıştır.

21 Temmuz 1969'da Franco 1947'de verdiği sözü yerine getirerek ölümünden sonra krallığın varisi olarak Bourbon hanedanından Prens Juan Carlos'u göstermiştir. Muhafazakâr kesim belli ölçüde yeni kralı benimsemiş olsa da solcu muhalefet aynı düşüncede olmamıştır. 1970’lerin henüz başında rejim sert bir muhalefet ile karşı karşıya kalmış ancak eski sert müdahalelerinden kaçınmıştır. Hali hazırda Avrupa Ortak Pazarına başvurusu bulunan Franco rejimi sert 
müdahalenin dış siyasette etkisinin olumsuz olacağını fark etmiştir. Oluşacak herhangi bir dıştaki olumsuz havanın iyi giden İspanyol ekonomisini bozabileceği endişesi verilen tepkilerin daha yumuşak olmasını sağlamıştır. Franco 1973'te aldığı hızlı bir karar ile Bakanlar Kurulu'nun başkanlığına ve hükümetin başına amiral Carrero Blanco’yu getirmiştir. 1936 yılından beri hem devletin hem de hükümetin başı olan Franco ilk defa hükümetin başı unvanından vazgeçmiştir. 1973 yılının sonuna gelindiğinde ise ETA örgütünün düzenlediği suikast sonucu Carrero Blanco hayatını kaybetmiştir. Franco 1974 yılında Blanco’nun yerine Carlos Arias Navarro’yu atamış ve aynı sene hastalanmıştır. Aynı yıl Portekiz'de Salazar'ın diktatörlüğü ordu darbesiyle devrilmiş ve Portekiz devleti demokrasiye hızlı bir geçiş yapmıştır. Portekiz’in yaşadığı bu değişim İspanya için iyi bir örnek olmuştur. 27 Eylül 1975'te ETA örgütü üyelerinin yakalanıp idam edilmesi dış siyasette İspanya'ya kapıları kapatmıştır. 20 Kasım 1975'te ise hasta olan Franco hayatını kaybetmiştir. Ölümünden iki gün sonra 22 Kasım'da halefi Bourbon hanedanından I. Juan Carlos göreve gelmiş ve anayasaya bağlı kalacağına ant içmiştir.

Bourbon hanedanının tekrar başa geçmesi sonrası Franco rejimine hizmet eden çevrenin tümü kral Juan Carlos'a hizmet etmeye devam etmiş ve Başbakan Carlos Arias Navarro'da krala bağlılığını sürdürmüştür. Kral Carlos değişim taleplerine karşılık vererek görevde olan Başbakan Arias’ın görevine son vermiştir. Arias'ın istifası sonrası hükümeti kurma görevini Adolfo Suárez’e vermiştir. Kral gibi başta Franco anayasasına yemin edip bağlı kalacağını söylese de değişimin gerekliliğini görmüştür. Kralında desteği ile Cortes yapılan oylama ile kendini feshetmiş ve Suárez ülkeyi demokratik seçimlere hazırlamıştır. 15 Haziran 1977 günü yapılan seçimde Suárez’in Demokratik Merkez Birliği partisi Cortes’teki 350 sandalyenin 165'ini almıştır. İspanyol Sosyalist İşçi partisi ise 118 sandalye ile Cortes’te yerini almıştır. Böylelikle demokratikleşmede önemli adımlar atılmaya başlamıştır. Suárez yönetiminin Bask ve Katalonya’ya özerklik vermesi sonrası birçok bölgeden özerklik talebi gelmesiyle 1981'de başbakan istifa etmiştir.

\section{3. İspanya'nın Demokratikleşmesi ve İber-Amerikan Kimliğinin İnşası}

1975 yılında Franco'nun ölümü ile demokratik sürece adım atan İspanya siyaseti 1982'ye kadar demokrasisini güçlendirmeye çalışmıştır. Bourbon hanedanının tekrar başa geçmesi sonrası Franco rejimine hizmet eden çevrenin tümü Kral Juan Carlos’a hizmet etmeye devam etmiş ve Başbakan Carlos Arias da krala bağlılığını sürdürmüştür. Buna rağmen Kral Carlos değişim 
taleplerine karşıllk vererek görevde olan Başbakan Arias'ın görevine son vermiş, hükümeti kurma görevini Adolfo Suárez'e vermiştir. Kralın da desteğiyle Cortes yapılan oylama ile kendini feshetmiş ve Suárez ülkeyi demokratik seçimlere hazırlamıştır. 15 Haziran 1977 günü yapılan seçimde Suárez'in Demokratik Merkez Birliği Partisi Cortes'teki 350 sandalyenin 165 'ini almıştır. İspanyol Sosyalist İşçi partisi ise 118 sandalye ile Cortes’te yerini almıştır. Suárez yönetiminin Bask ve Katalonya'ya özerklik vermesi sonrası birçok bölgeden özerklik talebi gelmesine yol açmıştır. Kral Juan Carlos'un 23 Şubat 1981'de askeri darbeye karşı demokrasiye bağl1lı̆̆ monarşinin İspanya toplumundaki ve siyasetinde toprak bütünlüğünün ve ulusal birliğin sembolü olarak rolünü güçlendirmiştir (Magone, 2018: 68).

Diğer tüm Batı demokrasileri İspanya'nın ilerlediği bu demokratik yolu ilgiyle karşılasalar da İspanya'nın İkinci Dünya Savaşı sırasında diğer faşist yönetimlerle işbirliği yapmış olması ülkenin Batı kampına katılımını geciktirmiştir. Ancak 1982 yılında İspanya NATO ittifakına katılarak Batı şemsiyesinde koruma altına alınmıştır. Aynı yıl içerisinde Haziran ayında Dünya Kupası düzenlenmiş ve Ekim ayı sonunda seçimlerde Sosyalist İşçi Partisi (PSOE) galip çıkmıştır. Seçimlerin ardından hükümeti kuran Felipe González, on iki yıl boyunca iktidarda kalmıştır (Gonzalez, 2018). Böylelikle ülke, iyi bir gelişim ve istikrara kavuşmuştur. PSOE, Avrupa Ekonomik Topluluğuna üyeliği ülkenin ekonomik geri kalmışlığı, otoriter sistemi ve uluslararası izolasyonu gibi tarihsel ve siyasi sorunlarına bir çözüm olarak gördüğü için Avrupa içinde bir İspanya'nın daha güçlü olacağına inanarak Avrupa'yla ilişkilerin geliştirmesini desteklemiştir. Aynı dönemde ordu, kilise, ticaret odaları ve diğer siyasi partiler de Avrupa ile ilişkilerin geliştirilmesi taraftarı olduğu için Avrupa entegrasyonu hedefi toplumda güçlü bir birleştirici etki yaratmıştır. Öte yandan, 40 yıllık diktatörlük sonrası Avrupalılaşma sürecine girilse de 1990'lı yıllar İspanya siyasi hayatında sivil toplum ve muhalefet zayıflı̆̆ını korumuştur. Siyasi özgürlüklerin garantörü olarak görülen üyelik için Sosyalist parti sekiz yıllık müzakere sürecinde Avrupa ortak pazarı için yapısal ekonomik reformlar başta olmak üzere 'iyi bir Avrupalı’ olmak için gerekli düzenlemeleri gerçekleştirmiştir (Youngs, 1999: 49). Hükümet, etkin ve sistemli bir politika izlemiş ve İspanyol halkının yaşam standartlarını yükseltmeyi amaçlamıştır. İstikrarlı büyüme kademeli olarak gerçekleşmiş ve nihayet 1986 yılı başvurusunda bir oy farkla İspanya'nın Avrupa Ekonomi Topluluğu'na üyeliği kabul edilmiştir. 
İspanya - Avrupa Birliği ilişkileri başlangıcından beri dalgalanmalarla ilerlemiştir. İspanya, zaman zaman Avrupa politikalarına yakın duran bir çizgide yer alırken, diğer taraftan kendi dış politikasını bağımsız inşa etme siyasetini yürütme çabasını göstermiştir. 1990'larda özellikle ekonomik sistemin Avrupa'yla uyumlaştırılması sürecinin sanc1lı olması bunda önemli rol oynamıştır. İspanya Eurozone bölgesine giren Euro kullanmayı kabul eden ilk devletlerden biri olmuştur. Eylül 1992'de \%3, Kasım'da \%5 ve Mayıs 1993'te \%8 olmak üzere peso defalarca devalüasyona uğramıştır. 1992 yılının Eylül ayındaki Kara Çarşamba'da hükümet geçici olarak sermaye kaçışına müdahale etmek zorunda kalmıştır (Youngs, 1999: 52). Felipe Gozalez, İspanya'nın hala Avrupa'ya çok ihtiyacı olduğunu ama koşulsuz tavizler verme konusunda eskisi gibi hevesli olmadıklarını dile getirmeye başlamıştır. Avrupa Birliği'ndeki konumunu güçlendiren İspanya hem Avrupa ile Latin Amerika arasındaki ilişkileri de güçlendirmiştir. 1991'de kurulan MERCOSUR (Güney Amerika Ortak Pazarı) ile Soğuk Savaş sonrası dönemde "yeni bölgelerarasıcılık" yaklaşımıyla ilişkilerini geliştirmek isteyen Avrupa Topluluğu İspanya’nın bu yolda bir köprü görevi görmesine destek vermiştir (Gragel, 2002). 1991-1993 yılları arasında İspanya'nın dış yatırımının \%60'1 Avrupa ülkelerineyken, 1994-1996 yıllarında bu oran \%33'e gerilemiş, ilk sırayı \%40 ile Latin Amerika ülkeleri almıştır (Youngs, 2000: 108). Bunda Felipe Gonzalez döneminde ortaya atılan İber-Amerikan kimliği fikri de etkili olmuştur. İber Yarımadası ülkeleriyle Orta ve Güney Amerika'daki İspanyolca ve Portekizce konuşan ülkeler arasındaki tarihi, kültürel, ekonomik ve siyasi bağlar üzerine inşa edilen bu ortak kimlik ilki 1991'de yapılan Uluslararası İber-Amerikan Zirvesi ile kurumsallaştırılmaya çalışmıştır. Bunun için Hispanik Kültür Enstitüsü ve devamında İber-Amerikan İşbirliği Enstitüsü kurulmuştur. 1996'da Sosyalistlere karşı zaferini ilan eden muhafazakâr Halk Partisi (PP) lideri José Maria Aznar da Madrid'te İber-Amerikan Genel Sekreterliğini kurarak İspanya ve Latin Amerika ilişkilerinin gelişmesini desteklemiştir. Fakat bu dönemde de bölge ülkeleriyle ilişkiler herhangi bir plan ya da strateji olmaksızın ortak kimlik ve kültüre vurgu yapılmasının ötesine geçmemiştir. Buna bölge ülkelerinin kendine has özelliklerini göz ardı eden ve ikili ilişkilere öncelik vermeyen bütüncül yaklaşım sebep olmuştur (Malamud, 2004). Latin Amerika'yı kavramsal, tarihi, sosyal, ekonomik ya da siyasi olarak bir birim olarak gören bu yaklaşım İspanya dış politikasının Atlantik'in diğer tarafında etkili olmasını engellemiştir. 


\section{4. İspanya’nın Avrupalı Kimliği ve Latin Amerika ile İlişkiler}

Atlantik Paktı ve Avrupa Topluluğu üyeliği, İspanya'nın daha önceki dönemlerde dış politikasında öncelikli yer verdiği Akdeniz politikalarının geri plana atılmasına neden olmuştur (Rein 1999; Villaverdi, 2007). Mağrip ve Ortadoğu'daki istikrarsızlık, geri kalmışlık ve göç sorunları İspanya güvenliği ve jeostratejik çıkarları için risk oluşturmaya başlarken, İspanya kimliğini ve bölgedeki rolünü Batılı güçler perspektifinden tanımlamaya başlamıştır. 2000 yılının Mart ayında yapılan bir kamuoyu araştırması, Avrupa kimliğinin olumlu bir imaja sahip olduğu, ulusal ya da bölgesel kimlik için tehdit edici görülmediği bulgulamıştır (Medrano \& Gutierrez, 2001: 772). Aynı yıl ikinci kez seçimleri kazanan ve ekonomik anlamda önemli adımlar atmak isteyen Aznar yönetimi, İspanya ekonomisini küreselleştirerek ekonomide en iyi on yılı yakalamıştır. Aznar, dış politikada ABD ile diğer yönetimlere göre daha yakın ilişkiler geliştirmeyi amaçlamış ve 11 Eylül saldırısına karşı ABD’nin yürüttüğü Irak ve Afganistan operasyonlarına açık şekilde destek vermiştir. Sekiz yıllık dönem içinde ABD’nin yanında yer almaya başlayan Aznar hükümetinin Avrupa politikalarını ikinci plana atmasından Fransa ve Almanya rahatsız olmuştur. Aznar'ın İspanya’ya küresel bir rol kazandırmak amacıyla Beyaz Saray’daki Bush yönetimiyle geliştirdiği ilişkiler Madrid ile Latin Amerikalı ülkelerin arasını açmış, İber-Amerikan kimlik politikalarına zarar vermiştir.

Bütün bu duruma rağmen içteki büyüme ve gelişim süreci sürmüş, José María Aznar 2004'e kadar iktidarda kalmıştır (Pierson, 2010: 189). 11 Mart 2004 sabahında Madrid'de işe giden insanları taşıyan trenlere bomba koyan teröristler (ETA), iki yüz kişinin ölümüne sebep olmuş ve bir anda ülke gündemi kaosa sürüklenmiştir (Burridge, 2014). Mart seçimlerinde Halk Partisi ağır yara almış ve Sosyalist İşçi Partisi lideri José Luis Rodríguez Zapatero başbakan olarak göreve başlamıştır. Zapatero döneminde İspanya cinsiyet eşitliği, çevrecilik, çokkültürlülük gibi çeşitli yasal düzenlemelerle demokrasisini güçlendirmeye çalışmıştır (Field 2009). Zapatero göreve gelirken İspanyol askerlerini Irak’tan çekeceği sözünü vermiş ve askerleri bölgeden çekmiştir. Zapatero’ya göre ABD’nin Irak işgaline destek vermek yanlış olduğu kadar İspanya'nın dış politika kimliğine tamamen aykırı bir karardı (Powell, 2009: 525). Dolayısıyla değişim sonrası ilk gelişme ABD’ye verilen desteğin azaltılması olmuştur. Bu süreçte Güney Amerikalı sosyalist iktidarlarla "küresel dayanışma" çerçevesinde bölge ülkeleriyle ilişki geliştirmeye yönelmiştir. AB direktiflerine rağmen Dış İşleri Bakanı Miguel Ángel Moratinos Küba’ya gitmiş, Castro 
yönetimiyle Eylül 2007'de ikili işbirliği antlaşması imzalamışıtır. Bu adımlar İspanya'nın Latin Amerika ve Avrupa Birliği ilişkilerini güçlendirme iddiasını açıkça tehlikeye atmıştır. Öte yandan Latin Amerikalı liderlerin açıklamaları İspanya'nın ortak bir İber-Amerikan kimliği oluşturma politikalarının yeterince başarılı olmadığını göstermektedir. Örneğin, 2009'da Zapatero'nun söylemleri eski Venezuela başkanı Hugo Chavez tarafından "kolonyalist klişe" olarak tanımlanmış, 2015'te eski İspanya Başbakanı Gonzalez'in Caracas’ı ziyaretini Bolivya Başkanı Evo Morales “yeni kolonyalizm” örneği olarak nitelemiştir (Wang, 2016: 3).

Küreselleşme ve ekonomik karşılıklı bağımlılığın arttı̆̆ çokkutuplu uluslararası sistemde orta büyüklükte bir güce sahip olan İspanya uluslararası kimliğini yeniden tanımlama çabasına girmiştir. Bunun için, sosyalist lider içeride ve dışarıda İspanya'ya kimliğine yön verecek değerler tanımlamıştır. Zapatero, barış, adalet, dayanışma, sosyal uyum, tolerans, sekülerlik gibi değerlerin iç işlerinde demokrasiyi dış işlerindeyse yumuşak gücü ve işbirliğini arttıracağına inanmıştır. Benzer şekilde uluslararası ilişkilerde etkili bir çoktaraflılığın içeride barışı ve ilerlemeyi sağlayabileceği düşünülmüş̧ür. ${ }^{2}$ Bunun için dış politikada "Afrika için Plan" ve "Asya için Plan" programlarını geliştiren hükümet, kendisini zaten İber-Amerikan topluluğunun bir üyesi olarak gördüğü için kendinden önceki yönetimler gibi Latin Amerika için planlı ve rasyonel bir dış politika izlemek için bir yol haritası belirlememiş̧ir (Gratius, 2010: 1-2).

2005 sonrası yavaşlayan ekonomi İspanya'yı reformlar yapmak zorunda bırakmış, kemer sıkma politikaları devreye sokulmuş ancak başarılı olunamamışıı. Daralan ekonomiye çare arayan ülke, 2008 dünya finansal krizinin Euro bölgesine etkisiyle ciddi ekonomik sarsıntı yaşamıştır (Neal \& García-Iglesias , 2013: 336-344). 2008 yılında \%8.6 olan işsizlik oranı 2013’te \%26.6'ya kadar tırmanmıştır (Eurostat, 2013: 2). Zapatero'nun ekonomiyi iyi yönetememesi sonucu Mariano Rojoy önderliğindeki Halk Partisi 2011 seçimlerini kazanarak iktidara gelmiştir. Krizi çözebilmek için Avrupa Birliği'nden mali kaynak talep etmiş ve gelen destek yeterli düzeyde olmamıştır. Pew Araştırma Merkezi Euro bölgesindeki ekonomik krizin etkilerine ve üye ülke kamuoylarında Birliğe verilen destekteki düşüşe işaret ederek Avrupa Birliğini “Avrupa'nın yeni hasta adamı" olarak tanımlamıştır (Pew, 2013). Yetersiz kaynak sağlanması ve AB'nin İspanya'nın ekonomi politikalarına ilişkin eleştirileri İspanyol siyasetçilerce hoş karşılanmamıştır. İspanya'da 2012'de \%60 olan destek 2013'te \%46'ya kadar gerilemiştir. Bu süreçte Kral Juan Carlos'un Suudi bir 
girişimciyle katıldığı fil avı partisiyle kızı Cristina ve damadının karıştığı yolsuzlukların basına yansıması İspanyolların siyasi sistemi daha fazla sorgulamalarına neden olmuştur (Magone, 2018: 67-68). Monarşinin sarsılan güvenilirliği tahta VI. Felipe'nin geçmesiyle sonuçlanmıştır. Bütün bu kötü sürece rağmen 2013'ün sonlarına gelindiğinde alınan tedbirlerin ilk meyveleri ortaya çıkmış ve İspanya ekonomisi toparlanma sinyali vermiştir. Ancak bu sinyaller gelecek süreçte İspanya ekonomisinin kötü gidişatını değiştirmemiştir. 21 Aralık 2015'te yapılacak seçim öncesi Brüksel yönetimi yeni seçilecek veya mevcut devam edecek yönetime uyarılarda bulunmuştur. 2015'e kadar yapılan reformlardan dolayı İspanya yönetimine teşekkürlerini sunan Brüksel yönetimi ancak yapılan reformların yetersiz olduğunu ve genişletilmesi gerektiğini belirtmiştir (Perez, 2015).

2015 seçimlerinde sandıktan birinci parti çıkmasına ve Mariano Rajoy iktidardaki yerini korumasina rağmen Halk Partisi meclisteki çoğunluğunu kaybetmiştir. Yaşanan 2015 hükümet krizinde 8 ay boyunca hükümetin kurulamaması İspanya kamuoyu için acı bir tecrübe olmuştur. Yaşanan istikrarsız siyasi yaşam, İspanya devletine olan güveni her anlamda azaltmış ve kimlik krizinin giderek büyümesine katkı sağlamıştır. Özellikle yaşadığı kriz ve yoğun işsizlik rakamları sonrası AB içinde ikinci Yunanistan vakası şeklinde yorumlamalara maruz kalmıştır. Ekonomik sorunlar siyasal sorunları da tetiklemiş̧ir. 1 Ekim 2017'de referanduma gideceklerini belirten Katalonya Özerk Bölgesi Başkanı Carles Puigdemont, İspanya yönetiminin Katalanların temel haklarını ihlal ettiğini öne sürmüştür (Özdemir, 2017). Avrupa Komisyonu ise iki tarafa diyalog tavsiyesinde bulunmuştur. Bağımsızlık referandumunda \%90'lık "Evet” oyu çımıştır. Bu durum ülkeyi anayasal bir krize sürüklemiştir. 1 Haziran 2018'de parlamentoda gerçekleștirilen güven oylamasını İspanyol Sosyalist İşçi Partisi kazanarak Mariano Rajoy yerine Pedro Sanchez'i başbakan yapmayı başarmıştır (BBC, 2018). Bu süreçte beş büyük partili seçim sistemi ideolojik olarak iki bloğa ayrılırken, VOX gibi aşırı sağcı, popülist partilerin de doğmasına neden olmuştur. 26 Mayıs 2019 tarihinde yapılan yerel, genel ve Avrupa parlamentosu seçimlerinin sonuçları, İspanyol toplumunda kutuplaşmanın arttığını doğrulamıştır (Simon 2019). 2 Haziran 2018'de göreve getirilen Pedro Sánchez mecliste yemin ederek görevine başlamıştır. Sánchez İspanya'ya ve $A B$ 'ye bir dizi reform ile ekonomiyi toparlayacağının sözünü vermiştir. Tüm bu gelişmelere rağmen 2019 Eurobarometre raporunda "Kendinizi ne kadar Avrupalı hissediyorsunuz?" sorusuna İspanyol halk1 \%85lik yüksek bir oranda olumlu cevap vermiştir (EC, 2019). İspanya'nın Avrupa kimliğine ilişkin verilen cevaplarda büyük oranda ortak coğrafyaya, demokratik değerlere ve ortak 
kültüre dayanılmıştır. Dolayısıyla İspanya dış politikasında Avrupa kimliğinin yeri İber-Amerikan kimliğinden daha öncelikli olduğu için Latin Amerika ile ilişkiler Avrupa Birliği ile ilişkilerin gölgesinde kalmaktadır. Avrupa Birliği de genişleme, entegrasyon, ekonomi ve mülteci krizi gibi sorunları nedeniyle küresel rolünü ve Latin Amerika ile ilişkilerini geri plana atmaktadır. Bununla birlikte dünya ekonomisinde ve siyasetinde yükselen bir güç olan Çin Halk Cumhuriyeti'nin İspanya'ya yaklaşımı dikkat çekicidir. 2021 yılının Mayıs ayında Başbakan Sanchez’i arayan Xi Jingping İmaparatorluk geçmişi olan iki ülkenin birbirini anlayıp desteklemesi gerektiğinin altını çizmiştir. Özellikle Latin Amerika ve Afrika'da üçüncü taraf işbirliğini güçlendirmeyi, halktan halka ve kültürel etkileşimi derinleştirmeyi önermiştir (Çin Dış İşleri Bakanlığı, 2021).

\section{Sonuç}

$\mathrm{Bu}$ çalışma İspanya dış politikasında imparatorluk döneminde önemli yeri olan Latin Amerika ile ilişkilerinin yerini sosyal-inşacı yaklaşımla analiz etmeyi amaçlamıştır. Bunun için çalışmada öncelikle, İspanya siyasi tarihinde sömürgecilik ve İmparatorluk dönemi incelenmiş, sonrasında İspanya iç savaşı ve Franco döneminin İspanya dış politikasına etkileri Latin Amerika ile ilişkiler bağlamında ele alınmıştır. Franco'nun İkinci Dünya Savaşı döneminde Hitler ve Mussolini gibi diğer faşist liderlerle işbirliğinin savaş sonrası Avrupa ekonomik, siyasi ve güvenlik inşasında İspanya'nın yer alamamasına neden olduğunun altı çizilmiştir. Bu nedenle Franco diktatörlüğü döneminde Hispanidad kavramıyla İspanya'nın dış politika kimliğinde İspanyolca konuşan ülkelerle bir yakınlık kurulmaya çalışılarak uluslararası izolasyonun aşılmaya çalışıldığı ortaya koyulmuştur. İspanya ancak 1986 y1lında Avrupa Ekonomik Topluluğuna katılmıştır. Bu süreçte dış politikada İber-Amerikan kimliği ile İspanya'nın Avrupa'da ve dünyada rolünü yeniden tanımlamaya çalışan liderler Madrid'in Avrupa ve Latin Amerika arasında bağlantıları güçlendirebileceğini iddia etmiştir. İspanya, ortak tarih, dil ve kadere vurgu yaparak kendini Latin Amerika ülkelerinin bir parçası olarak tanımlasa da bölge ülkelerine bütüncül yaklaşımı, farklılıkları ve ikili ilişkileri göz ardı edişi İspanya'nın bölge ülkeleriyle etkili bir ilişki geliştirmesini engellemiştir. Öte yandan İspanya'nın Avrupalılaşan ekonomi-politikası on yıllık bir yükselişe geçerken 2004 yllındaki Doğu genişlemesi AB'nin diğer okyanus ötesi bölgelerle ilişkileri geliştirme gündemini askıya almıştır. 2008 dünya finansal krizinin Euro bölgesine etkisi, İspanya-AB ilişkileri için büyük bir bağlılık sınavı olmuştur. 2013 yılında işsizliğin \%27’ye kadar 
yaklaştı̆̆ İspanya'da her şeye rağmen AB'ye ve Euro kullanımına yüksek destek korunmaktadır. 2019 yılında yapılan Eurobarometre araştırmasına göre kendini Avrupalı olarak tanımlayan İspanya vatandaşlarının oranı $\% 85^{\prime}$ 'dir. Avrupa, sol partiler için içerideki ekonomik ve siyasi sorunlara karşı demokrasinin bir garantörü olarak görüldüğü gibi, sağ partiler için İspanya kimliğine şekil veren dini ve kültürel geçmişi ifade ederek içerideki bölgesel ayrılıkçı hareketler için birleştirici bir ulusal proje olarak görülmektedir. Dolayısıyla 21. yüzyıl İspanya dış politikasında Latin Amerika ile ilişkiler AB ile ilişkilerin gölgesinde kalmaktadır.

\section{Kaynakça}

AIZPEOLEA, L. R., 2013. "The Day ETA Struck a Lethal Blow to the Franco Regime”, https://english.elpais.com/elpais/2013/12/18/inenglish/1387374599_382537.html. $\underline{(27.06 .2021)}$.

BBC, 2018, Spain PM Mariano Rajoy Faces defeat in Friday No-Confidence Vote, (Erişim Tarihi:25.03.2021), https://www.bbc.com/news/world-europe-44319670

BURRIDGE, T., 2014. “Spain Remembers Madris Train Bombings 10 Years on”, https://www.bbc.com/news/world-europe-26526704 (19.07.2021).

CARRERO B., 1973. "Was Assassinated The Terrorist Organization was Responsible wor the Bombing', https://english.elpais.com/elpais/2013/12/18/inenglish/1387374599_382537.html (22.07.2021).

CORDERO, G., MONTERO, J. R., 2015. “Against Bipartyism, Towards Dealingnment?’, South European Society and Politics, 20 (3), ss.357-379.

ÇAPAN, F., GÜVENÇ, B., 2017. “Kavimler Göçü ve Batı Roma İmparatorluğu'nun Çöküşü”, 21. Yüzyılda Eğitim ve Toplum, 6 (18), ss. 629-640.

Çin Dış İşleri Bakanlığı 2021. https://www.fmprc.gov.cn/mfa_eng/zxxx_662805/t1879031.shtml

DATO, J. R., SOJKA, A., 2020. "The Rise of (Faulty) Euroscepticism? The Impact of a Decade of Crises in Spain", South European Society and Politics, 1 (1), ss. 1-29. 
DEMETER, M., GOYANES M., 2020. "Antecedents of Leaving the European Union: The Role of Nostalgia and Attitudes Towards Diversity in Spain, Italy, and Greece', Mediterranean Politics, Routledge, London.

DIEZ, A., 2015. "Economic Crisis Denting Spaniards' Confidence in Europe”, https://english.elpais.com/elpais/2015/06/12/inenglish/1434124110_142342.html (01.07.2021).

DÖNMEZ, F., 2018. “İspanyol Mavi Tümeni: Franco'nun Vefa Borcu”, https://www.gazetebilkent.com/ispanyol-mavi-tumeni-franconun-vefa-borcu/ (11.07.2021).

EL PAİS, 2011. "Brussels Revises Upward Spain's Deficit for 2010 and 2011”, https://english.elpais.com/elpais/2012/10/22/inenglish/1350913642_518419.html $\underline{(26.06 .2021)}$.

EC, 2019. “Eurobarometer”, https://europa.eu/eurobarometer/surveys/detail/2225 (18.07.2021).

EUROSTAT, 2013. "Euro Area Unemployment Rate",

https://ec.europa.eu/eurostat/documents/2995521/5164586/3-31102013-BP-

EN.PDF/ac1c16fc-35ba-4d32-a0a0-91e9409eda8f (21.07.2021).

ESCARTIN, A. R., 2020. "Populist Challenges to EU Foreign Policy in the Southern Neighbourhood: an Informal and Illiberal Europeanisaition?', 1 (1), ss.1-21.

FIELD, B. N., 2010. “A 'Second Transition' in Spain?”, South European Society and Politics, 14 (4), ss.379-397.

FINNEMORE, M. 1996. National Interests in International Society, Ithaca, Cornell University Press.

GILLESPIE, R., 2015. "Spain and the Mediterranean: Southern Sensitivty, European Aspirations" Mediterranean Politics, 1 (2), ss. 193-211.

GONZALEZ, F., 2018. "Biographies" https://www.encyclopedia.com/people/history/spanishand-portuguese-history-biographies/felipe-gonzalez 03.07.2021. 
GRATIUS, S.,2010. '’Why does Spain not have a policy for Latin America?', Frida: A European Think Thank for Global action, Policy Brief, 29 (1), ss. 5.

GRUGEL, J., 2002. "Spain, the European Union and Latin America: Governance and Identity in the Making of 'New' Inter-Regionalism." Real Instituto Elcano, http://www.realinstitutoelcano.org/wps/portal/rielcano_en/contenido?WCM_GLOBAL_C ONTEXT=/elcano/elcano_in/zonas_in/dt9-2002 (22.07.2021).

GROBMANN, J. 2014. "Bulletin of Spanish Studies: Hispanic Studies and Researches on Spain, Portugal and Latin America", Bulletin of Spanish Studies, 91 (5), 755-771.

HALPERIN, S. and PALAN, R. 2015. Legacies of Empire: Imperial Roots of the Contemporary Global Order, Cambridge University Press, Cambridge.

HISTORY, 2011. “Franco Captures Barcelona”, https://www.history.com/this-day-inhistory/franco-captures-barcelona (04.07.2021).

HITTI, P., 2012. History of the Arabs, Palgrave Macmillan, London.

JACKSON R., SORENSEN, G., 2007. Intrudiction to International Relations. Theories and Approaches, Oxford University Press, Oxford.

KATZENSTEIN, P. (ed.) 1996., The Culture of National Security: Norms and Identity in World Politics, New York, Columbia University Press.

KENNEDY, P. 2005. Büyük Güçlerin Yükselişi ve Çöküşleri, Türkiye İş Bankası Kültür Yayınları, İstanbul.

KRATOCHWILL, F. V. 1995. Rules, Norms and Decisions, Cambridge University Press, Cambridge.

KURTULUŞ, B., 2005. “Amerika Kıtası'nın Keşfi: Kuzey Amerika - Asya Bağlantısı”, Sosyal Siyaset Konferansları Dergisi, 0 (49), ss. 874-886.

KURUL, E., 2015. "Kartacalı Hannon ve Batı Afrika Kıyılarına Seyrüsefer”, Phaselis, 1 (1), ss. 231-260.

LEE, S. J., 2004. Avrupa tarihinden kesitler 1494-1789, Dost Kitabevi, Ankara, 295s. 
MAKKI, M., 1992. The Political History of Al-Andalus (92/711-897/1492), The Legacy of Muslim Spain, London.

MALAMUD, C., 2004. "Spain and Latin America: Global vs. Bilateral Relations." Real Instituto Elcano, http://www.realinstitutoelcano.org/wps/portal/rielcano_en/contenido?WCM_GLOBAL_C ONTEXT=/elcano/elcano_in/zonas_in/dt58-2004. (22.07.2021).

MEDEIROS, E., 2016. "European Union Cohesion Policy and Spain: A Territorial Impact Assessment', Regional Studies, 1 (1), ss. 1259-1269.

MEDRANO, J.D., GUTIERREZ, P., 2010. “'Nested Identities National and European Identy in Spain', Ethnic and Racial Studies, 24 (5), ss.753-778.

MORGENTHAU, H. J., 1970. Uluslararası Politika, Baskın Oran ve Ünsal Oskoy (çev.), Türk Siyasi İlimler Yayınları, Ankara.

NEAL, L., and GARCÍA-IGLESIAS, M. C., 2013. "The economy of Spain in the euro-zone before and after the crisis of 2008”, The Quarterly Review of Economics and Finance, 53 (4), ss. $336-344$

ONUF, N. G., 2012. World of Our Making: Rules and Rule in Social Theory and International Relations, Routledge, New York.

ÖZDEMİR, M., 1992. “'Endülüs’ün Yıkılış Sürecinde Öne Çıkan Bazı Hususlar’', Ankara İlahiyat Fakültesi Dergisi, 36 (1), ss. 233-254.

ÖZDEMİR, Ö., 2017. “Katalonya'daki Bağımsızlık Referandumuyla İlgili Bilinmesi Gerekenler', https://www.bbc.com/turkce/haberler-dunya-41437383. (10.07.2021).

PADRON, F. M. (1990). Historia del Descubrimiento y Conquista de America. Madrid: Editorial Gredos, (Aktaran: Elik, Süleyman; Bal, Faruk), (2014), Çağdaş Uluslararası Sistemin Kaynağı ve İlk Dönemi Olarak İspanya-Portekiz Atlantik Sistemi 1493-1648, Gazi Üni. İIBF Dergisi,16(1), 88-117. 
Journal of Social Research and Behavioral Sciences, Volume: 7 Issue: 13 Year: 2021

PELLICER, L., 2018. "In New Blow to Blocked Budget”, https://english.elpais.com/elpais/2018/11/21/inenglish/1542789223_130846.html.

(11.07.2021).

PEREZ, A., 2015. 'EU Calls on Next Spanish Government to Extend Economic Reforms', https://english.elpais.com/elpais/2015/12/07/inenglish/1449483747_214429.html. (05.07.2021).

PEW, 2013. "The New Sick Man of Europe",

https://www.pewresearch.org/global/2013/05/13/the-new-sick-man-of-europe-theeuropean-union/. (19.07.2021).

PHILLIPS, W. D., PHILLIPS, C. R., 2016. İspanya’nın Kısa Tarihi, (çev. Tuna Erkmen), Boğaziçi Üniversitesi Yayınevi, İstanbul.

PIERSON, P., 2010. The History of Spain, Greenwood Histories of the Modern Nations, London.

POWELL, C., 2010. “A Second Transition, or More of the Same? Spanish Foreign Policy Under Zapatero', South European Society and Politics, 14 (4), ss. 519-536.

REIN, R.(ed) Spain and Mediterranian since 1898, London: Frank Cass.

SANCHEZ, $\quad$ P., "We $2019 . \quad$ Must Protect https://www.europarl.europa.eu/news/en/press-room/20190109IPR23019/pedro-sanchezwe-must-protect-europe-so-europe-can-protect-its-citizens. (13.07.2021).

SANDER, O. 2004. Anka'nın Yükselişi ve Düşüşü: Osmanlı Diplomasi Tarihi Üzerine Bir Deneme, Ankara, İmge.

SANZ, R. P., 2001. “The Mediterranean Policiy of Franco's Spain” Mediterranean Historical Review, 16 (2), ss. 45-68.

SIMON, P., 2019. “The Multiple Spanish Elections of April and May 2019: The Impact of Territorial and Left-right Polarisation’, South European Society and Politics, 1 (1), ss. 1 35 .

SMITH, S., 2007. Introduction, International Relations Theories, Eds. Oxford University Press, Oxford. 
STAVRIDIS, S., 2005. “ 'Europeanisation' Versus Traditioal FPA: Recent Lessons from the Spanish and Greek FP Cases’’ ECPR Joint Sessions of Workshops, 1 (1), ss. 1-22.

TEPEROGLOU, E., BELCHIOR, A. M., 2020. “'Is 'Old Southern Europe' Still Eurosceptic? Determinants of Mass Attitudes before, during and after the Eurozone Crisis', 1 (1), ss. 127.

TORREBLANCA, J. I., 2010. "Ideas, Preferences and Institutions: Explaining the Europeanization of Spanish Foreign Policy, Arena Working Papers, 1 (26), ss. 1-38.

TZORTZIS, I., 2014. “'Regime Dispensability and Democratic Transitions: A Case Comparison of Spain and Turkey', Perspectives on European Politics and Society, 15 (4), ss. 416-430.

ÜÇOK, B., 1968. Emeviler - Abbasiler, Ankara Üniversitesi İlahiyat Fakültesi Yayınları, Ankara.

VILLAVERDE, J. A. N., 2007. “The Mediterranean: A Firm Priority of Spanish Foreign Policiy?", Mediterranean Politics, 5 (2), ss. 129-147.

WALTZ, K., 2000. "Realist Thought and Neorealist Theory", in Andrew Linklater (der.), International Relations: Critical Concepts in Political Science, Londra and New York: Routledge, 21-37.

WANG, S., 2016. “A Familial Relation? Spain and Latin America in the 21st Century”, Council on Hemispheric Affairs, Washington, 7.

WENDT, A. 1999. Social Theory of International Politics, Cambridge, Cambridge University Press.

WENDT, A. 1992 “Anarchy is What States Make of it: The Social Construction of Power Politics”, International Organization, Vol. 46, No. 2, 391-425.

YOUNGS, R., 2007. “The Domestic Politics of Spanish European Economy Policy, 1986-94”, South European Society and Politics, 4 (1), ss.48-70.

YOUNGS, R., 2007. “Spain, Latin America and Europe: The Complex Interaction of Regionalism and Cultural Identification', 5 (2), ss.107-128.

ZEHFUSS, M., 2002. Constructivism in International Relations, The Politics of Reality, Cambridge University Press, Cambridge. 